\title{
BIOAVAILABILITY OF PHENOLIC COMPOUNDS AND REDOX STATE OF MURINE LIVER AND KIDNEY AS SEX-DEPENDENT RESPONSES TO PHYTOEXTRACTS
}

\author{
BIODISPONIBILIDAD DE COMPUESTOS FENÓLICOS Y ESTADO REDOX DE HÍGADO Y RIÑÓN DE \\ RATÓN COMO RESPUESTAS SEXO-DEPENDIENTE A FITOEXTRACTOS
}

\author{
Claudia Albrecht ${ }^{1,2}$, María C. Cittadini ${ }^{1,2}$, María L. Guzmán ${ }^{3}$, Alejandra M. Canalis ${ }^{1}$, Mirta A. Valentich ${ }^{1}$, \\ María E. Olivera ${ }^{3}$, Elio A. Soria ${ }^{1}$.
}

\begin{abstract}
Background: Plant extracts can be obtained to carry bioactive compounds, useful for prevention and treatment of different illnesses. This also supports the intake of teas as functional beverages. Nonetheless, it is incompletely known whether these extracts can act as effective sources and vehicles de phenolic compounds (phenolics/polyphenols) to reach their targets. Objective: To establish whether phytoextract ingestion modified in a sex-dependent manner the phenolic bioavailability and redox response in liver and kidney. Method: BALB/C mice ingested for a month $100 \mathrm{mg} / \mathrm{Kg} / \mathrm{d}$ of extracts (tea-like) from Aspidosperma quebracho-blanco (AQB), Lantana grisebachii (LG) or llex paraguariensis (IP). Then, phenolics, peroxides and nitrites were analyzed by spectrophotometry. Also, phenolic permeation from digested and undigested extracts was evaluated in vitro with a rat jejunum-based assay. Results: Phenolic permeation depended on extract digestion. In males, IP showed a special time course of hepatic phenolics, whereas all extracts decreased renal phenolics at 15 days. Extracts induced hepatic lipoperoxides at 15 days. LG reduced renal hydroperoxides at 15 days and hepatic nitrites at 30 days, whereas $A Q B$ and IP reduced renal lipoperoxides and nitrites at 30 days. In females, extracts reduced hydroperoxides, with LG and AQB also reducing lipoperoxides. IP increased renal lipoperoxides at 30 days. Conclusion: IP was a relevant phenolic source. Sex-dependent responses were found in all variables, which should be considered to prevent misleading generalizations in phytodrug bioprospecting.
\end{abstract}

Key words: quebracho; Ilex paraguariensis; Lantana; absorption; oxidation-reduction

\section{Resumen}

Antecedentes: Es posible obtener extractos vegetales que contengan compuestos bioactivos, aplicables en la prevención y el tratamiento de diferentes enfermedades. Esto apoya además el consumo de infusiones como bebidas funcionales. No obstante, no se conoce completamente si estos extractos son capaces de actuar como fuentes y vehículos efectivos de compuestos fenólicos (fenoles/polifenoles) para alcanzar sus blancos. Objetivo: Establecer si la ingestión de fitoextractos modifica de manera sexodependiente la biodisponibilidad de fenoles y la respuesta redox en hígado y riñón. Métodos: Ratones BALB/C consumieron durante un mes $100 \mathrm{mg} / \mathrm{Kg} / \mathrm{d}$ de extracto (derivado de infusión), proveniente de Aspidosperma quebracho-blanco (AQB), Lantana grisebachii (LG) o llex paraguariensis (IP). Luego, se analizaron por espectrofotometría fenoles, peróxidos y nitritos. Además, se evaluó in vitro la absorción de fenoles de extractos digeridos y no digeridos con un ensayo que emplea yeyuno de rata. Resultados: La absorción de fenoles dependió de la digestión del extracto. En machos, IP mostró una curva temporal de fenoles hepáticos, mientras todos los extractos los disminuyeron a los 15 días. Los extractos indujeron lipoperóxidos hepáticos. $L G$ redujo hidroperóxidos renales a los 15 días y nitritos hepáticos a los 30 días, mientras $A Q B$ e IP redujeron lipoperóxidos y nitritos en riñón a los 30 . En hembras, los extractos disminuyeron los hidroperóxidos, con $L G$ and $A Q B$ también reduciendo lipoperóxidos. IP incrementó lipoperóxidos renales tras 30 días. Conclusión: IP fue una fuente relevante de fenoles. Se hallaron respuestas sexo-dependientes en todas las variables, lo que debe ser considerado para evitar generalizaciones incorrectas en la bioprospección de drogas vegetales.

Palabras clave: quebracho; llex paraguariensis; Lantana; absorción; oxidación-reducción

1 Instituto de Investigaciones en Ciencias de la Salud (INICSA), CONICET and Facultad de Ciencias Médicas, Universidad Nacional de Córdoba, Argentina;

2 Instituto Nacional del Cáncer, Ministerio de Salud, Argentina;

3 Unidad de Investigación y Desarrollo en Tecnología Farmacéutica (UNITEFA), CONICET and Departamento de Farmacia, Facultad de Ciencias Químicas, Universidad Nacional de Córdoba, Argentina.

4 Email de contacto: easoria@fcm.unc.edu.ar 


\section{Introduction}

Polyphenols or phenolics are redox-active compounds with health potential ${ }^{(1-3)}$. They can be provided as diet phytonutrients, phytodrugs and phytoextract constituents ${ }^{(1)}$. However, the last source is empirically used worldwide without further confirmation of its efficient role in phenolic delivery. Thus, assessment of absorption, distribution and activity acquires relevance to support judicious pharmaconutritional applications of plant derivatives, which are subject to several physiological conditions ${ }^{(4)}$.

Previous reports determined that aqueous tealike extraction of three Argentinean plants produces bioactive phytoextracts ${ }^{(5,6)}$ : Lantana grisebachii Stuck. (Verbenaceae) (LG), Aspidosperma quebracho-blanco Schltdl. (Apocynaceae) (AQB), and Ilex paraguariensis $A$. St.-Hil. (Aquifoliaceae) (IP). The last one is highly consumed as tea by humans, mainly in America $^{(7)}$.

Also, metabolic organs are highly exposed to these compounds given their involvement in phenolic clearance ${ }^{(8)}$. This might affect redox homeostasis of liver and kidneys, after phytochemical delivery from extracts. Therefore, redox stress of hepatic and renal tissues might be a risk of phenolic over-exposure, leading to organ damage and development of several chronic diseases (e.g. metabolic syndrome, hepatic dysfunction, renal failure, etc. $)^{(9,10)}$. Although they have been extensively proposed as xenohormetic agents $^{(1)}$, their toxicity has been also reported in accordance with dose and user characteristics $^{(11,12)}$. In this regard, vital conditions can be determinant of phytochemical bioavailability and effects ${ }^{(13)}$. Hence, a sexdependent potential of the described phenolicproviding extracts might be found in murine organs implicated in kinetics of these compounds, to extend knowledge about natural plant-based resources and their health impact.

\section{Materials and Methods}

\section{Phytoextract processing}

Plant collection (location: $31^{\circ} 15^{\prime} 40^{\prime \prime} \mathrm{S}, 64^{\circ} 27^{\prime} 50^{\prime \prime}$ W; period: summer) and processing were performed as previously done ${ }^{(11,14)}$. Briefly, botanical identification and repository were performed by the RIOC Herbarium (UNRC, Argentina). The extracts were obtained from plant aerial parts by a water-based photoprotected thermoassisted method $\left(1 \mathrm{~g}\right.$ in $5 \mathrm{~mL}$ of $95^{\circ} \mathrm{C}$ water for $1 \mathrm{~h}$, with constant agitation, to reach room temperature). The obtained infusions were freeze-dried and their phenolic contents were analyzed: LG $(10.23 \pm 0.43 \mathrm{mg} / \mathrm{g}, \quad 58.46 \%$ of flavonoids), AQB $(2.57 \pm 0.14 \mathrm{mg} / \mathrm{g}, 37.74 \%$ of flavonoids), and IP $(21.77 \pm 1.37 \mathrm{mg} / \mathrm{g}, 24.48 \%$ of flavonoids). In order to simulate gastric digestion, each phytoextract was incubated at $37^{\circ} \mathrm{C}$ for $1 \mathrm{~h}$ after acidification with hydrochloric acid up to $\mathrm{pH}$ 2.0. Then, the reaction was stopped by neutralizing with sodium bicarbonate solution up to $\mathrm{pH} 7.4^{(15)}$.

\section{Phytoextract intestinal permeation}

To assess gastric effects on intestinal permeation of extract phenolics, permeability evaluation was performed with digested and undigested extracts. To do this, adult Wistar male rats (200-300 g) bred and sacrificed under standard conditions were euthanized with $\mathrm{CO}_{2}$. Intestines were rapidly removed to separate the jejunum and wash it with cold $\mathrm{pH} 7.4$ Krebs buffer. Then, it was stored in the same solution, which was continuously gassed with $\mathrm{CO}_{2} / \mathrm{O}_{2}(5 / 95)$ mixture. Pieces of approximately $2 \mathrm{~cm}$ were opened along their mesenteric border. After that, each section was mounted in an Ussing chamber (Multichannel Ussing Chamber EASY MOUNT-2400, Physiologic Instruments ${ }^{\circledR}$, USA) as flat sheets on a segment holder, with an exposed area of 0.5 $\mathrm{cm}^{2}$. Five $\mathrm{mL}$ of Krebs buffer were added to each compartment of chambers and the solutions were gassed. The chambers were maintained at $37^{\circ} \mathrm{C}$ by water jackets. Before and during the experiment, membrane integrity was monitored by measuring transepithelial electric resistance and voltage with electrodes at both sides of the membrane (Multichannel VCC MC6-6S (Physiologic Instruments $\AA$, USA) connected to the software Acquire \& Analyze 2.0). Resistance values $\geq 40 \Omega$ were the viability criteria ${ }^{(16)}$. After a $15 \mathrm{~min}$ stabilization period, total volume of the donor chambers was replaced with the corresponding extract solutions, which were dissolved in $\mathrm{pH} 7.4 \mathrm{Krebs}^{\text {buffer }}{ }^{(17)}$, with a final concentration of $50 \mathrm{mg} / \mathrm{mL}$. After $20 \mathrm{~min}$, a 200 $\mu \mathrm{L}$ aliquot was taken from the acceptor chamber and quantified according to the Folin-Ciocalteu technique (described below). Results were expressed as absolute $\mu \mathrm{g} / \mathrm{mL}$ of total phenolics and their percentages in acceptor chamber respect to the donor one.

\section{In vivo conditions}

As previously done ${ }^{(11,14)}, 2$-month-old BALB/C mice of both sexes were treated and sacrificed according to EU Directive 2010/63/EU for animal experiments. Animals were bred under standard laboratory conditions and fed ad libitum with commercial diet $(200 \pm 13 \mathrm{~g} / \mathrm{kg} /$ day; Cargill SACI, 
Argentina) and potable water $(150 \pm 10$ $\mathrm{mL} / \mathrm{kg} /$ day; Aguas Cordobesas SA, Argentina). Forty eight animals were separated into two time groups: 15 and 30 days, to be treated with a solution prepared from the rehydrated extracts of AQB, LG or IP (extract dose: $100 \mathrm{mg} / \mathrm{kg} /$ day equivalent to $\sim 1.5 \mathrm{~L} /$ day of human intake), with a control group which did not receive additional treatments for the corresponding comparisons (C). The extract solutions were administered to the animals daily intrabuccally during four weeks. Thus, 3 females and 3 males received each extract for each time. General status, weight, food, and water consumption were controlled weekly. After mice sacrifice, kidneys and liver were taken and weighed. These organs were mechanically homogenized and extracted $10.1 \mathrm{~g}$ of tissue in $1 \mathrm{~mL}$ of $60 \%$ methanol and $2.5 \%$ trichloroacetic acid, for 30 minutes at $50^{\circ} \mathrm{C}$ ) to assay tissue content-standardized organic parameters.

\section{Measurement of redox-related compounds}

Total phenolics were measured in murine tissues and intestinal permeation samples according to the Folin-Ciocalteu technique. Briefly, the samples were mixed with $2 \mathrm{~N}$ Folin reactant, water, and saturated sodium bicarbonate solution $(1: 1: 6: 2 \mathrm{v} / \mathrm{v} / \mathrm{v} / \mathrm{v})$, and incubated for 30 minutes in darkness at $37^{\circ} \mathrm{C}$. Absorbance was measured at $750 \mathrm{~nm}$ to calculate concentrations using a standard curve of gallic acid $(5-160 \mu \mathrm{g} / \mathrm{mL})^{(11,14)}$.

Hydroperoxides and lipoperoxides (AHP and LHP, respectively) were analyzed in murine tissue homogenates. Briefly, samples were mixed with a xylenol orange-based reactant $(1: 10 \mathrm{v} / \mathrm{v})$, and incubated for $30 \mathrm{~min}$. Then, standardized peroxides concentrations were expressed as 560 $\mathrm{nm}$ absorbance percentage respect to control ${ }^{(6)}$.

Nitrites are markers of nitric oxide production. Briefly, samples were mixed with Griess reactants A $\quad(0.1 \% \quad$ naphthylethylenediamine dihydrochloride) and $B$ ( $1 \%$ sulphanilamide in 0.1 $\mathrm{N} \mathrm{HCl})(1: 1: 1 \mathrm{v} / \mathrm{v} / \mathrm{v})$ for 15 min before reading at $550 \mathrm{~nm}^{(18)}$. Concentrations were calculated from a sodium nitrite standard curve to be expressed as $\%$ of control.

\section{Statistical analysis}

Data were expressed as mean \pm standard error from three separate experiments performed in triplicate. ANOVA models were used to evaluate differences of variables among treatments. Then, the Tukey test was used for mean comparisons, considering a significant level of $p<0.05$. Regressive models were used to study time- dependent changes. Associations were assessed by path analysis in the InfoStat 2012 software.

\section{Results}

\section{Phenolic permeability}

Absolute permeation of phenolics was similar for the three undigested extracts (IP, LG and AQB) despite of their different phenolic concentrations. However, they responded differently after simulated digestion. Thus, digestion decreased phenolic permeation from AQB extract (3.91 \pm 0.53 vs $0.42 \pm 0.01 \mathrm{GAE} \mu \mathrm{g} / \mathrm{mL}$, for undigested and digested extract respectively) $(p<0.05)$, but it did not modify LG outcomes $(03.61 \pm 0.03$ vs $02.01 \pm 0.14 \mathrm{GAE} \mu \mathrm{g} / \mathrm{mL}$ pre and post digestion). Contrarily, this process increased permeation of IP phenolics, which amounted $04.08 \pm 0.14$ to $11.58 \pm 0.62 \mathrm{GAE} \mu \mathrm{g} / \mathrm{mL}$ after digestion, to reach the highest amounts $(p<0.05)$.

\section{Phenolic availability}

Liver: Time curves of phenolic level showed similar patterns in the three experimental groups (IP, LG and $A Q B$ ) in a sex-dependent manner. Nonetheless, male IP outcome at 30 days deviated from the other treated groups (Figure $1 \mathrm{~A}$ and $1 \mathrm{~B}$ ).

Kidney: It was found a transient decrease of phenolics from IP, LG and AQB in males at 15 days $(p<0.05)$, without other changes seen in both sexes (Figure 1C and 1D). 

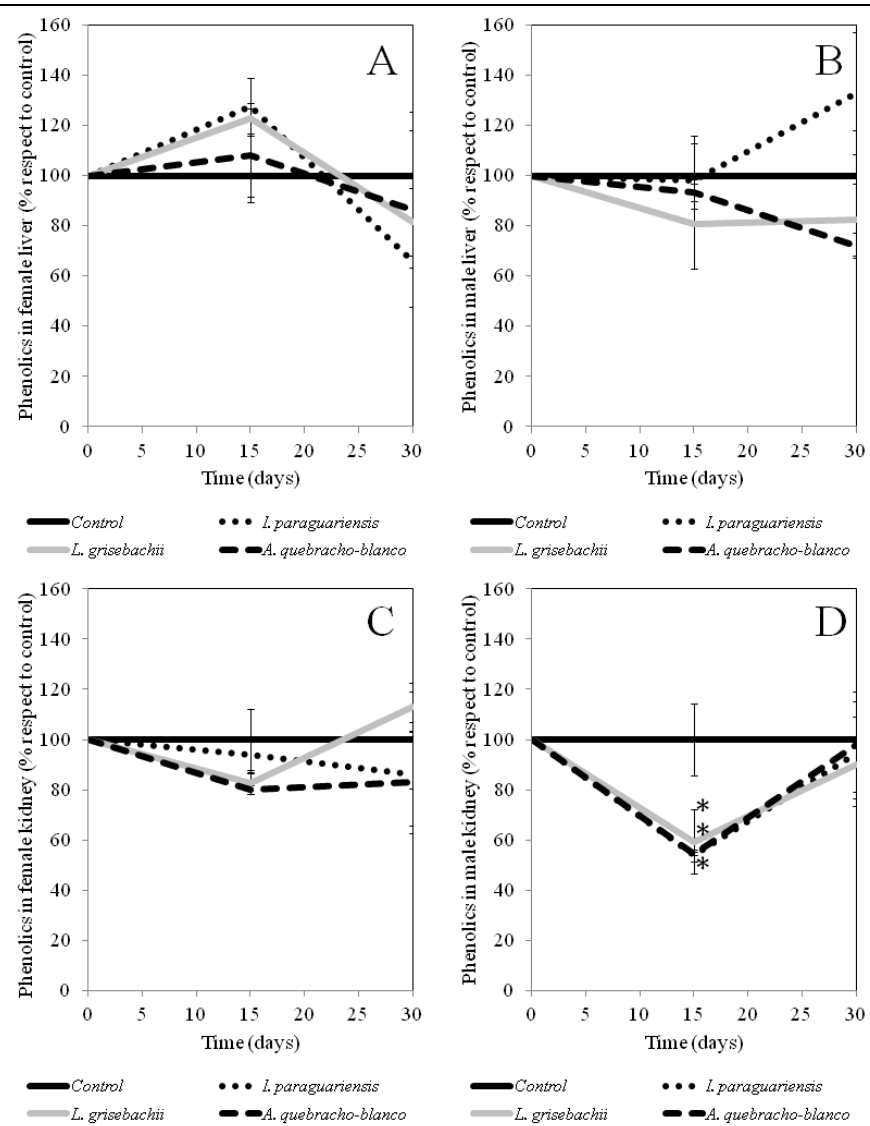

Control

-. L paraguariensis

Figure 1. Total phenolics in murine liver (A: female, B: male) and kidneys (C: female, $D:$ male) treated with $0 \mathrm{mg} / \mathrm{kg} /$ day or $100 \mathrm{mg} / \mathrm{kg} /$ day of each infusive extract $(A$. quebracho-blanco, L. grisebachii, or I. paraguariensis). Mean $\pm \mathrm{SE}$ were expressed as percentage respect to control $\left({ }^{*} p<0.05\right)$.

\section{Peroxides}

Liver: In males, production of hydroperoxides were unaffected by IP, LG and AQB. Hepatic lipoperoxides were induced by these extracts after 15 days $(p<0.05)$, with a recovery after 1 month. This reduction was lower in case of IP $(p<0.05)$. On the other hand, the three treatments reduced hydroperoxides in females after a month $(p<0.05)$. LG and AQB also reduced lipoperoxides $(p<0.05)$ (Figure $2 A)$.

Kidney: In males, LG reduced hydroperoxides respect to $C$ after 15 days $(p<0.05)$, but this effect was not observed after 1 month. AQB and IP reduced renal lipoperoxides after 1 month intake $(p<0.05)$. In females, LG and IP increased lipoperoxides in kidneys after 1 month $(p<0.05)$. Other effects were not found (Figure 2B).

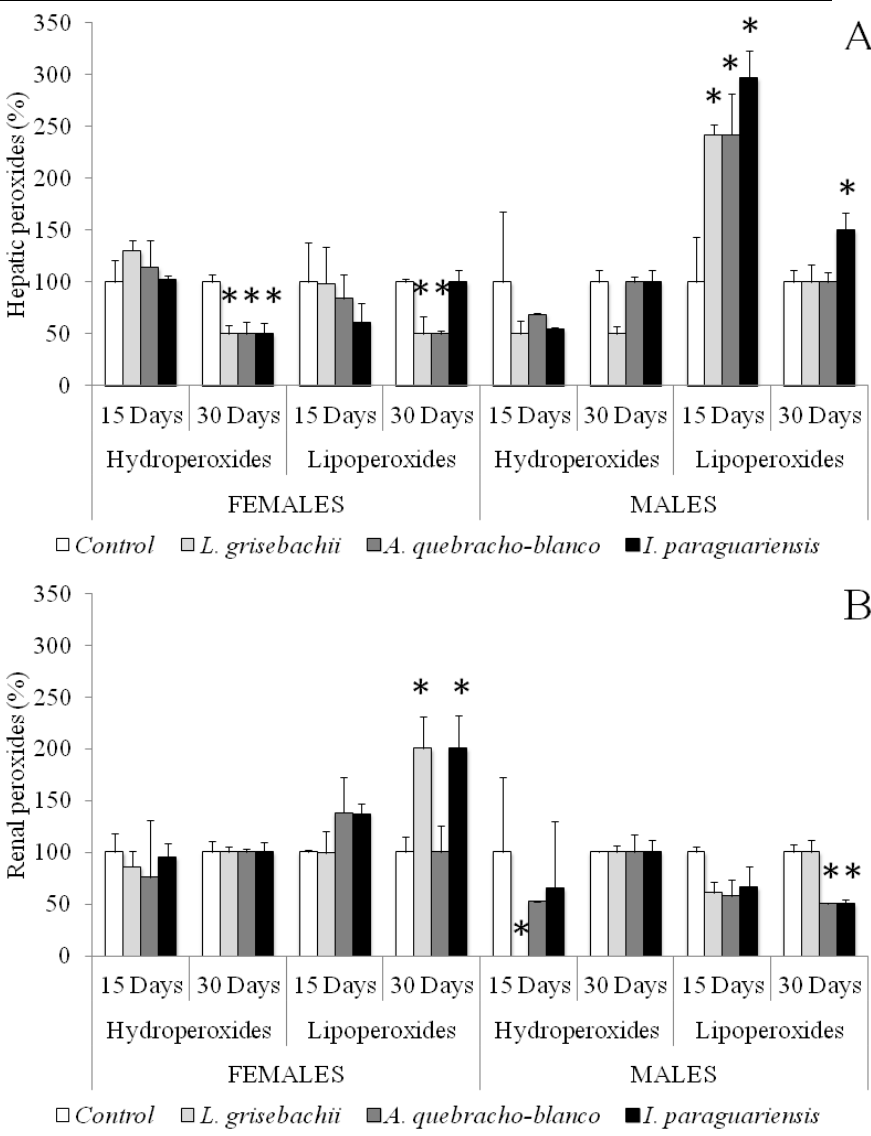

Figure 2. Hepatic (A) and renal (B) peroxidation in BALB/C mice treated with 100 $\mathrm{mg} / \mathrm{Kg} /$ day of each plant extract vs. control (without treatment). Means $\pm \mathrm{SE}$ were expressed as percentage respect to control $\left({ }^{*} \mathrm{p}<0.05\right)$.

\section{Nitrites}

Liver: In males, LG decreased nitrites after 1 month $(p<0.05)$, whereas AQB and IP did not modify this parameter. Females did not show any response to treatments (Figure 3 ).

Kidney: In males, AQB intake reduced nitrites at 15 and 30 days, and IP showed the same effect after 1 month $(p<0.05)$. Females did not respond to treatments (Figure 3 ). 


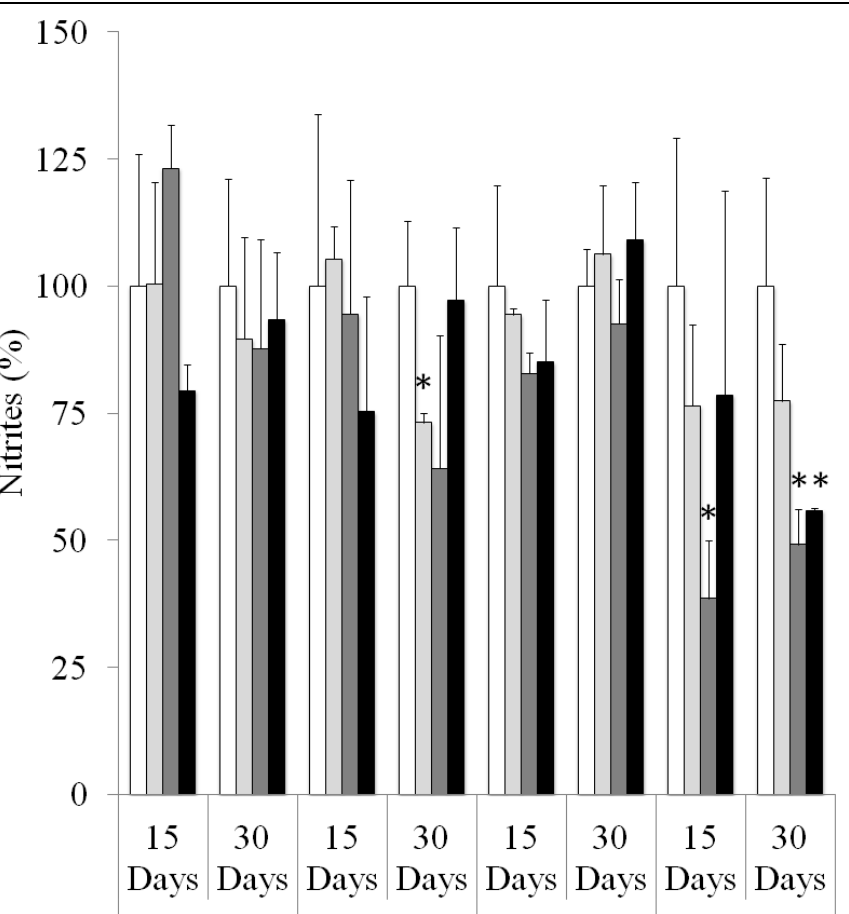

FEMALES MALES FEMALES MALES

LIVER

KIDNEY

$\square$ Control $\square$ L. grisebachii $\square$ A. quebracho-blanco $\mathbf{\square}$. paraguariensis

Figure 3. Hepatic and renal nitrites in BALB/C mice treated with $100 \mathrm{mg} / \mathrm{Kg} /$ day of each plant extract vs. control (without treatment). Means $\pm \mathrm{SE}$ were expressed as percentage respect to control $\left({ }^{*} p<0.05\right)$.

\section{Discussion}

Plants are suitable sources of bioactive compounds by optimal infusion extraction, which can be taken advantageously by pharmaceutical and health approaches ${ }^{(19)}$. Given that phytochemical properties involve different factors in vivo, kinetic and dynamic studies are required. Among phytochemicals, phenolics are a major group, and their biomedical properties depend on plant taxa and environmental conditions. Thus, bioprospecting of new candidates, such as $A$. quebracho-blanco, L. grisebachii and $I$. paraguariensis, included assessment of phenolic permeability and availability. These plants were selected in accordance with previous researches $^{(7,14,20)}$.

The studied plant extracts showed differential phenolic permeability with a higher passage of IP compounds after simulated gastric digestion. In this sense, it is well known that molecular structures of free and conjugated forms have different capacities to be absorbed ${ }^{(21)}$. Unpublished data indicate that LG contains heavy molecules (e.g. iroids) and minor glycosides, AQB contains hydroxybenzoic derivatives, whereas IP contains quinic derivatives and elevated polyphenol glycosides, which release aglycones after digestion to be better absorbed $^{(22)}$. In contrast, acid digestion of AQB and LG extracts did not improve permeation, given their lower content of glycosides and the presence other compounds, which are incorporated as non-hydrolyzed forms ${ }^{(23,24)}$.

After absorption, phenolic compounds arrive at metabolic organs, such as liver and kidney, to be excreted after completing the enterohepatic cycle $^{(13)}$. Given the high hepatic metabolism, low phenolic permeation does not allow these phytochemicals to be accumulated in liver, as in the case of AQB and LG. Oppositely, the elevated permeation of digested IP phenolics favoured their hepatic accumulation after exposure, which is regulated by metabolizing enzymes in a sex-dependent manner ${ }^{(25,26)}$.

When phenolics arrived at kidney, they can scavenge peroxides leading to reciprocal diminution ${ }^{(27)}$. This was confirmed by results found at 15 days of treatment in the present work. Complementarily, plant compounds can induce their excretion, which is reported for the three genera: Ilex ${ }^{(28)}$, Lantana ${ }^{(29)}$, and Aspidosperma ${ }^{(30)}$. These effects were temporary with later normalization of parameters at 30 days, showing acquired tolerance to treatments ${ }^{(31)}$.

Under the assayed conditions, intake of three phytoextracts induced hepatic lipoperoxidation in males at 15 days, which recovered at 30 days. In accordance with our results, outcomes were not specifically related to phenolic content. In this regard, an overload of xenobiotics could lead to oxidative and lipid disturbances in liver ${ }^{(32)}$, which demanded a metabolic enhancement in order to counteract it ${ }^{(25)}$, with males being highly susceptible to these compounds ${ }^{(26)}$. Given the upper lipoperoxides found at 15 days respect to those at 30 days in both sexes, initial response might depend on phase I enzymes, which can trigger oxidative stress $^{(32)}$, whereas later response might involve phase II detoxifying enzymes ${ }^{(25,33)}$. This fact was according to the redox profile found in female mice, as they exhibit higher activities of phytochemical-metabolizing enzymes (e.g. UDP-glucuronosyltransferases 1a1 and 125$)^{(33)}$. Thus, females take advantage of antioxidant phytochemicals at low doses ${ }^{(21)}$.

Regarding renal redox status, IP and LG induced lipid peroxidation in females at 30 days. In contrast, IP and AQB reduced lipoperoxides in males. Sex-dependent differences are wellknown and are determined at both pharmacological levels: kinetics and dynamics ${ }^{(34)}$. These effects might depend on non-phenolic molecules present in the extracts, which differentially compromise redox homeostasis of kidney. In consequence, further studies are encouraged to confirm it. In this sense, these plants contain chemical stressors, such as 
benzopyrene, alkaloids and lantadenes ${ }^{(35)}$, as well as antioxidants (e.g. vitamins) ${ }^{(36)}$.

On the other hand, nitrosative stress is a deleterious condition for cells and tissues, and its modulation has been proposed in prevention of chronic diseases ${ }^{(37)}$. In the present work, extracts maintained normal levels in liver and kidney of nitrites (nitrosative markers), or even reduced them ${ }^{(38)}$. About this, antioxidant phytochemicals cause down-regulation of inducible nitric oxide synthase, which is the precursor of these markers ${ }^{(38)}$. Furthermore, nitrite decrease was related to modulation of lipid peroxidation in males, thus indicating their involvement in tissue stress, with this relation being proposed ${ }^{(39,40)}$. Also, males responded more than females to regulation by phytoextracts, as previously established $^{(14)}$.

\section{Conclusion}

Lantana grisebachii, Aspidosperma quebrachoblanco and Ilex paraguariensis represent possible sources of phenolic compounds. In this regard, digested $I$. paraguariensis provided higher amounts of permeated phenolics to be assimilated by organism. Also, extracts were related to an appropriate nitrosative state and to sex-dependent redox activities in liver and kidney. Overall, results confirmed phenolic delivery, and promote bioprospecting of plant derivatives with health value.

\section{Acknowledgements}

The authors wish to acknowledge the assistance of the Consejo Nacional de Investigaciones Científicas y Técnicas (CONICET) and the Universidad Nacional de Córdoba (SECYT203/14), both of which provided support and facilities for this investigation.

\section{Bibliography}

1. Ramos Elizagaray SI, Soria EA. Arsenic immunotoxicity and immunomodulation by phytochemicals: Potential relations to develop chemopreventive approaches. Recent Pat Inflamm Allergy Drug Discov 2014;8: 92-103.

2. Mitjavila MT, Moreno J. The effects of polyphenols on oxidative stress and the arachidonic acid cascade. Implications for the prevention/treatment of high prevalence diseases. Biochem Pharmacol 2012;84: 1113-1122.

3. Giri TK, Alexander A, Ajazuddin, Barman TK, Maity S. Infringement of the barriers of cancer via dietary phytoconstituents capsaicin through novel drug delivery system. Curr Drug Deliv 2016;13: 27-39.

4. Osland EJ, Memon MA. Are we jumping the gun with pharmaconutrition (immunonutrition) in gastrointestinal oncological surgery? World J Gastrointest Oncol 2011;3: 128-130.
5. Goleniowski ME, Bongiovanni GA, Palacio L, Nuñez CO, Cantero JJ. Medicinal plants from the "Sierra de Comechingones", Argentina. J Ethnopharmacol 2006;107: 324-341.

6. Soria EA, Goleniowski ME, Cantero JJ, Bongiovanni GA. Antioxidant activity of different extracts of Argentinian medicinal plants against arsenic-induced toxicity in renal cells. Hum Exp Toxicol 2008;27: 341-346.

7. Bracesco N, Sanchez AG, Contreras V, Menini $T$, Gugliucci $A$. Recent advances on llex paraguariensis research: Minireview. J Ethnopharmacol 2011;136: 378384.

8. Heitman E, Ingram DK. Cognitive and neuroprotective effects of chlorogenic acid. Nutr Neurosci 2014; 2014:140925080725000.

9. Veskoukis AS, Tsatsakis AM, Kouretas D. Dietary oxidative stress and antioxidant defense with an emphasis on plant extract administration. Cell Stress Chaperon 2012;17: 11-21.

10. Tsao R. Chemistry and biochemistry of dietary polyphenols. Nutrients 2010;2: 1231-1246.

11. Cittadini MC, Canalis AM, Albrecht C, Soria EA. Effects of oral phytoextract intake on phenolic concentration and redox homeostasis in murine encephalic regions. Nutr Neurosci 2015;18: 316-322.

12. Murakami A. Dose-dependent functionality and toxicity of green tea polyphenols in experimental rodents. Arch Biochem Biophys 2014:557: 3-10.

13. Clifford MN, Van der Hooft JJ, Crozier A. Human studies on the absorption, distribution, metabolism, and excretion of tea polyphenols. Am J Clin Nutr 2013;98: 1619S$1630 S$.

14. Canalis $A M$, Cittadini MC, Albrecht $C$, Soria $E A$. In vivo redox effects of Aspidosperma quebracho-blanco Schltdl., Lantana grisebachii Stuck and Ilex paraguariensis A. St.-Hil. on blood, thymus and spleen of mice. Indian J Exp Biol 2014;52: 882-889.

15. Tenore GC, Campiglia $P$, Giannetti $D$, Novellino $E$. Simulated gastrointestinal digestion, intestinal permeation and plasma protein interaction of white, green, and black tea polyphenols. Food Chem 2015;169: 320-326.

16. Bravo-Osuna I, Vauthier C, Chacun H, Ponchel G. Specific permeability modulation of intestinal paracellular pathway by chitosan-poly(isobutylcyanoacrylate) coreshell nanoparticles. Eur J Pharm Biopharm 2008;69: 436-444.

17. Clarke LL. A guide to Ussing chamber studies of mouse intestine. Am J Physiol Gastrointest Liver Physiol 2009;296: G1166-G1166.

18. Soria $E A$, Bongiovanni GA, Díaz Luján C, Eynard AR. Effect of arsenite on nitrosative stress in human breast cancer cells and its modulation by flavonoids. Nutr Cancer 2015;67: 659-663.

19. Biasutto L, Mattarei A, Sassi N, Azzolini M, Romio M, Paradisi C, Zoratti M. Improving the efficacy of plant polyphenols. Anticancer Agents Med Chem 2014;14: 1332-1342.

20. Borneo R, León AE, Aguirre A, Ribotta P, Cantero JJ. Antioxidant capacity of medicinal plants from the Province of Córdoba (Argentina) and their in vitro testing in a model food system. Food Chem 2009;112: 664-670.

21. Del Rio D, Rodriguez-Mateos A, Spencer JPE, Tognolini $M$, Borges G, Crozier A. Dietary (poly)phenolics in human health: Structures, bioavailability, and evidence of protective effects against chronic diseases. Antioxid. Redox Signal 2013;18: 1818-1892.

22. Rivelli DP, Almeida RL, Ropke CD, Barros SBM. Hydrolysis influence on phytochemical composition, antioxidant activity, plasma concentration, and tissue distribution of hydroethanolic Ilex paraguariensis extract components. J Agric Food Chem 2011;59: 8901-8907. 
Phenolic availability and redox response.

23. Liu $Y$, Zhang D, Wu Y, Wang D, Wei $Y$, et al. Stability and absorption of anthocyanins from blueberries subjected to a simulated digestion process. Int $J$ Food Sci Nutr 2014;65: 440-448.

24. Makkar HP, Blümmel $M$, Becker K. Formation of complexes between polyvinyl pyrrolidones or polyethylene glycols and tannins, and their implication in gas production and true digestibility in in vitro techniques. Br J Nutr 1995;73: 897-913.

25. Patel R, Maru G. Polymeric black tea polyphenols induce phase II enzymes via Nrf2 in mouse liver and lungs. Free Radic Biol Med 2008;44: 1897-1911.

26. Wen $D$, Huang $X$, Zhang $M$, Zhang $L$, Chen J, et al. Resveratrol attenuates diabetic nephropathy via modulating angiogenesis. PLOS ONE 2013;8:e82336.

27. Psotová J, Lasovský J, Vičar J. Metal-chelating properties, electrochemical behavior, scavenging and cytoprotective activities of six natural phenolics. Biomed Pap Med Fac Univ Palacký Olomouc Czech Repub 2003;147: 147-153.

28. Heck Cl, De Mejia EG. Yerba mate tea (llex paraguariensis): A comprehensive review on chemistry, health implications, and technological considerations. $J$ Food Sci 2007;72: R138-R151.

29. Vyas N, Argal A. Diuretic potential of oleanolic acid isolated from Lantana camara. Asian J Pharm Clin Res 2012; 5: S196-S199.

30. Miller JH, McCoy KD, Colman AS. Renal actions of the a2-adrenoceptor agonist, xylazine, in the anaesthetised rat. N Z Vet J 2001;49: 173-180.

31. Patwardhan B, Gautam M. Botanical immunodrugs: scope and opportunities. Drug Discov Today 2005;10: 495-502.

32. Kirby GM, Nichols KD, Antenos M. CYP2A5 induction and hepatocellular stress: An adaptive response to perturbations of heme homeostasis. Curr Drug Metab 2011;12: 186-197.

33. Wu B, Kulkarni K, Basu S, Zhang S, Hu M. First-pass metabolism via UDP-glucuronosyltransferase: a barrier to oral bioavailability of phenolics. J Pharm Sci 2011;100: 3655-3681.

34. Waxman DJ, Holloway MG. Sex differences in the expression of hepatic drug metabolizing enzymes. Mol Pharmacol 2009;76: 215-228.

35. Parimoo HA, Sharma R, Patil RD, Sharma OP, Kumar $P$, Kumar N. Hepatoprotective effect of Ginkgo biloba leaf extract on lantadenes-induced hepatotoxicity in guinea pigs. Toxicon 2014;81: 1-12.

36. Zarban A, Toroghi MM, Asli M, Jafari M, Vejdan $M$, Sharifzadeh $G$. Effect of vitamin $C$ and $E$ supplementation on total antioxidant content of human breast milk and infant urine. Breastfeed Med 2015;10: 214-217.

37. Bixby $M$, Spieler $L$, Menini $T$, Gugliucci A. Ilex paraguariensis extracts are potent inhibitors of nitrosative stress: A comparative study with green tea and wines using a protein nitration model and mammalian cell cytotoxicity. Life Sci 2005;77: 345-358.

38. Korkmaz A, Kolankaya D. Inhibiting inducible nitric oxide synthase with rutin reduces renal ischemia/reperfusion injury. Can J Surg 2013;56: 6-14.

39. El Gamal AA, Al Said MS, Raish M, Al-Sohaibani M, AlMassarani SM, Ahmad A. Beetroot (Beta vulgaris L.) extract ameliorates gentamicin-induced nephrotoxicity associated oxidative stress, inflammation, and apoptosis in rodent model. Mediators Inflamm 2014; $2014: 983952$.

40. Mustafa AG, Bani-Ahmad MA, Jaradat AQ, Allouh MZ. Tempol protects blood proteins and lipids against peroxynitrite-mediated oxidative damage. Exp Biol Med 2014; 240: 109-112. 